or otherwise), to continue the same active endeavours for Pr. Charles as thou hast done for me, and not whine for my misfortunes in a retired way, but, like thy father's daughter, vigorously assist Pr. Charles to regain his own. This thou canst not refuse to perform, knowing the reality of thy love to him who is eternally thine,

\title{
Charles R.
}

If I should go into Scotland, though I know thou wilt be willing that I swear Mountrose of my bedchamber, yet (to be punctual in my word to thee) I desire thy approbation to it, as also to the rest of my letter, with all possible speed. If thou hearest that I have put myself into Fairfax's army, be assured that it is only to have the fittest opportunity for my going to Lynn in a disguise, if not by other ways.

\section{$\mathrm{XXV}$.}

Dear Heart,

New-Castle, May 15th, 1646.

The necessity of my affairs hath made me send Jack Ashburnham unto thee, who at this present is the most (and with the greatest injustice) persecuted of all my servants, and meerly for his fidelity to me, which is so well known to thee, that I need neither recommend him to thy care, nor take the pains of setting down the present state of my affairs, and how they have changed since I came from Oxford, and why it is so long since I wrote to thee, referring all to his faithful relation, as likewise what I desire thee to do for my assistance; so transferring at this time the freedom of my pen to his tongue, I rest eternally thine,

\section{Chatles R.}

I owe Jack $£ 9,200$, which I earnestly recommend thou wouldst assist him in for his payment. 